\author{
NATASZA LISOWSKA \\ Uniwersytet im. Adama Mickiewicza w Poznaniu \\ Wydział Teologiczny
}

\title{
Metafora ciemnej nocy w dziełach Johna Henry'ego Newmana
}

John Henry Newman w swojej bogatej, teologiczno-filozoficznej spuściźnie nierzadko odnosi się do metafory nocy, która ma u niego ten sam zakres znaczeń, co w Biblii. Tymczasem można zauważyć także przykłady, w których stosuje on metafore „,ciemnej nocy”, precyzyjniejszą i przywołującą na myśl „noc ciemną" jako jeden z etapów życia duchowego. Pomimo że aluzja ta jest tak silna, w dziełach Newmana nie sposób odnaleźć bezpośrednich odniesień do św. Jana od Krzyża i jego dzieł. Kiedy bowiem używa terminów pokrewnych: „noc próby” (night of trial) ${ }^{1}$ lub „ciemny dzien” (dark day) ${ }^{2}$, wprawdzie odnosi je do braku pociechy w rzeczach stworzonych, ale nie ma na uwadze procesu oczyszczania człowieka, w którym Bóg zdaje się nieobecny, a dusza cierpi na myśl o własnym potępieniu.

U Newmana „ciemna noc” obrazuje natomiast stan świata po grzechu pierworodnym, udręczenia i zwodzenia przez złego ducha oraz oczekiwania na powtórne przyjście Chrystusa. Odnosi się także do rzeczywistości osobistej drogi każdego człowieka-pielgrzyma, który może uniknąć skrywanych przez ciemność nocy niebezpieczeństw jedynie poprzez zdanie się na Boże prowadzenie w akcie wiary. Osoba może też pogłębić tę ciemność w wyniku własnych grzechów, wyłączając się tym samym spod Bożej opatrzności indywidualnej. Ona zaś objawia się właśnie w nadprzyrodzonym przewodnictwie skierowanym do konkretnej osoby.

1 J.H. Newman, Sen Geroncjusza, w: Rozmyślania i modlitwy. Poezje, thum. Z. Kubiak, Warszawa 1995, s. 546; tenże, The Dream of Gerontius, w: Verses on Various Occasions, London-New York-Bombay 1903, s. 370.

2 Tenże, Parochial and Plain Sermons, t. 4, London-New York-Bombay-Calcutta 1909, s. 197. 


\section{1. „Ciemna noc” (the night dark) jako metafora ziemskiego życia}

Jednym z utworów, w którym wyraźne miejsce zajmuje metafora ciemnej nocy u Newmana, jest jego słynna modlitwa poetycka pt. The Pillar of the Cloud, znana bardziej jako hymn Lead, kindly Light. Za inspirację posłużył mu niewątpliwie motyw wędrówki Izraela przez pustynię oraz symbolika słupa obłoku za dnia i ognia w nocy. Te ostatnie są wyrazem obecności, opieki i przewodnictwa Bożego, miejscem, z którego On przemawia (por. Wj 13,21, Ps 99,7, Mdr 18,3), a także tronem, na którym spoczywa Mądrość (por. Syr $24,4)$. I chociaż tytuł poematu wskazuje na słup obłoku, to $\mathrm{z}$ uwagi na fakt, iż ten uformowany $\mathrm{z}$ ognia jest $\mathrm{w}$ Księdze Wyjścia $\mathrm{z}$ nim tożsamy (por. Wj 14,19-20), wydaje się, że Newman mógł wzmocnić przekaz swojego utworu, nadając mu tytuł The Pillar of the Fire, który byłby bardziej adekwatny do pory nocy, którą przywołuje. Wiersz napisał 16 czerwca 1833 roku, w obliczu bezsilności, jaką odczuł wówczas, gdy jego statek nieoczekiwanie utknął w Cieśninie św. Bonifacego. Zdał się wówczas na Bożą mądrość i opatrzność:

Prowadź mnie, Światło, swą błogą opieką, Światło odwieczne!

Noc mroczna (the night is dark), dom mój tak bardzo daleko, Ty więc mnie prowadź. Nie proszę rajów odległych widoku, Starczy promyczek dla jednego kroku.

$[\cdots]$

Tyś zawsze trwało, gdym przez głuchą ciemność,

Przez bór, pustynię błąkał się dumny.

O, czuwaj nade mną, aż noc przeminie,

Aż świt odsłoni te drogie postacie,

Którem ukochał niegdyś, którem stracił ${ }^{3}$.

Po odczytaniu modlitwy Newmana przez pryzmat biblijnego opisu wyjścia Izraelitów z niewoli widoczne jest, że tylko wiara w Boga i wierność Mu mogą uchronić człowieka przed lękiem, jaki budzi noc. Jak podaje bowiem Księga Wyjścia (Wj 14,19-20) wówczas, gdy Egipcjanie, dogonili Izraelitów na brzegu Morza Czerwonego i szli przez całą noc na ich tyłach, tylko Żydzi potrafili dostrzec Boga pod postacią ognia; wojska faraona widziały natomiast w tym miejscu ciemność. Zdane na własne zmysły, nie mając oparcia w Bogu jako Prawdzie, wyolbrzymiały odgłosy nocy i ulegały złudzeniom przerażających cieni (por. Mdr 17,4). Jednocześnie nie znalazły one wsparcia w mężnym

3 Tenże, Rozmyślania i modlitwy, tłum. Z. Kubiak, Warszawa 1995, s. 7; tenże, Meditations and Devotions, London-New York-Bombay-Calcutta 1907, s. 156. 
sercu, bo sumienie poruszone grzechem nieustannie ich oskarżało. Tak ten stan pogrążenia w wewnętrznej ciemności, który korespondował z okolicznościami zewnętrznymi opisuje Księga Mądrości:

Niegodziwcy, co zamyślili ujarzmić lud święty, legli, uwięzieni ciemnością, zniewoleni długą nocą:

zbiegowie przed wieczną Opatrznością - zamknięci pod strzechą.

Ci, którzy mniemali, że się ukryją z grzechami tajemnymi

pod ciemną zasłoną zapomnienia,

pogrążeni zostali w ciemnościach, wielce zatrwożeni

i przerażeni zjawami ${ }^{4}$.

Z kolei wierzący, których figurą w Księdze Mądrości są Izraelici, potrafią dostrzec złudność świata materialnego, widząc w ciemności właściwe proporcje zjawisk dzięki światłu Bożemu. W codziennych okolicznościach życia są zdolni do owocnego działania, przeciwnie do tych, którzy jak Egipcjanie ignorują Boga i nie wzbudzają żalu za swoje grzechy. Odnosząc się do wspomnianej nocy, w której wojska faraona dogoniły Izraelitów, natchniony pisarz komentuje to wydarzenie:

Cały [...] świat był zalany światłem

i oddawał się pracy bez przeszkody:

tylko nad nimi [wojskami egipskimi - N.L.] uciążliwa noc się rozpostarła, obraz mroków, które miały ich ogarnąć.

A sami byli dla siebie większym ciężarem niż ciemnośćs.

Przyjmując jako uzasadnione, że John H. Newman w swojej modlitwie The Pillar of the Cloud wraz z motywem wędrówki Izraelitów przez pustynię przejmuje jednocześnie występującą w Księgach Wyjścia i Mądrości metaforę nocy, można założyć, że oznacza ona w jego utworze: niebezpieczeństwa czyhające na człowieka w życiu doczesnym, zwłaszcza w obliczu niewiary oraz stan nieprawego sumienia, które zaburza właściwy ogląd rzeczywistości i funkcjonowanie w świecie. Na konwencję modlitwy Newmana musiało mieć wpływ również wezwanie z Book of Common Prayer, które w czasie Wigilii Paschalnej wypowiadane jest w kościołach anglikańskich:

Módlmy się. O, Boże, który prowadziłeś swój lud przez słup chmury w ciągu dnia

i płomień ognia wśród nocy: Pozwól i nam, którzy służymy Ci na ziemi,

${ }^{4} \operatorname{Mdr} 17,2-3$.
${ }_{5} \operatorname{Mdr} 17,19$. 
przystąpić do radości niebiańskiego Jeruzalem, w którym wszelka łza zostanie otarta i gdzie Twoi święci nieustannie głoszą Twoją chwałę; przez Chrystusa, Pana naszego. Amen' .

Warto zwrócić uwagę na cel drogi wskazany w powyższym tekście liturgicznym, tj. niebiańskie Jeruzalem, w którym mieszkają święci. Jednoznacznie ukazuje on wędrówkę już nie jako drogę, którą przebyli Izraelici, ale tę, jaką muszą przejść dzieci Kościoła. Ten sam cel określa także Newman, nazywając miejsce u kresu drogi „domem” (home) i wyrażając nadzieję spotkania $\mathrm{z}$ utraconymi przyjaciółmi. I chociaż można polemizować z tą interpretacją, zważywszy na fakt, że Newman podczas pisania utworu poetyckiego przebywał za granicą i mógł mieć na myśli także Anglię, za którą tęsknił, to przemawiają za nią także inne jego dzieła, w których domem nazywa zarówno Kościół katolicki, jak i właśnie Niebo?

Pewien paralelizm motywu wędrówki wśród nocy widoczny jest ponownie w XX wieku m.in. w twórczości hiszpańskiego poety Luisa Rosalesa (1910-1992), którego utwór pt. De cómo el hombre que se pierde llega siempre a Belén ukazał się w hiszpańskim miesięczniku kulturalnym „Cuadernos Hispanoamericanos” w lutym 1956 roku. Pierwsza zwrotka tego utworu została wykorzystana jako refren w kanonie z Taizé pt. De noche:

Wśród nocy idziemy, wśród nocy, do źródła Twojego życia, tylko pragnienie jest światłem, tylko pragnienie jest światłem ${ }^{8}$.

W pozostałych zwrotkach utworu L. Rosalesa odnajdujemy dopełnienie tego duchowego pejzażu, który pozostaje w konwencji drogi:

${ }^{6}$ The Book of Common Prayer, b.r.m.w., s. 290, https://www.bcponline.org/ [dostęp: 29.12.2018].

${ }^{7}$ W wykładzie Newmana pt. The Glories of Mary for the Sake of Her Son, znajduje się wezwanie: „O, zwiastunko dnia! O, nadziejo pielgrzyma! Prowadź nas wciąż, jak prowadziłaś w ciemną noc, przez ponurą pustynię, poprowadź nas do naszego Pana Jezusa, poprowadź nas do domu" - tenże, Discourses to Mixed Congregations, London-New York-Bombay 1906, s. 359.

${ }^{8} \mathrm{~W}$ oficjalnym thumaczeniu na język polski kanon rozpoczyna się słowami: „W ciemności idziemy, w ciemności”. Nie odpowiada on jednak oryginalnemu tekstowi, tj. „De noche iremos” oraz przekładom na inne języki - por. Kanony z Taize, http://cantusmundi.blogspot.com/2013/01/ de-noche-taize.html [dostęp: 28.12.2018]. W ramach partii śpiewanej przez solistę wspólnota Taizé ułożyła własne zwrotki: „Dobrze znam to źródło wody żywej, które bije, chociaż jest noc. Jego blask nigdy nie jest zaciemniony i wiem, że stopniowo przybliża się cała jego jasność, chociaż jest noc. To wieczne źródło ukryte jest w tym żywym chlebie, aby dać życie, chociaż jest noc. To żywe źródło, którego pragnę, widzę w tym chlebie życia, chociaż jest noc" - De noche iremos, http://blogs.periodistadigital.com/nidopoesia.php/2008/09/04/p186292 [dostęp: 28.12.2018]. 
W nocy, kiedy mrok

całego świata łączy się,

pójdziemy, zachowując duszę

nieskalaną i czystą.

W nocy, kiedy droga

pachnie rozmarynem i turzycą,

pójdziemy z pasterzami,

odszukać Ciebie.

W nocy, kiedy jest zimno, a udręka ma ludzkie oblicze, zawsze znajdzie się miejsce, w którym płacz porusza kolebką niewinnego?

\section{2. „Ciemna noc” (the dark night) jako obraz świata materialnego po grzechu pierworodnym}

John Henry Newman w kazaniu pt. The Visible Temple z 1842 roku, podejmując temat widzialnego Kościoła, który wznosi się na niewidzialnej świątyni wiary i miłości zbudowanej w imię Chrystusa ${ }^{10}$, odnosi się także do Jego narodzin w Betlejem. Zdaniem Newmana, wtedy właśnie po raz pierwszy Syn Boży wzniósł na ziemi swoją duchową świątynię. Kondycję świata doczesnego, którą zastał, Newman opisuje w kazaniu poprzez odwołanie do surowości ciemnej nocy oraz jaskini, które jednak nie zdołały pochłonąć i złamać Chrystusa, zarówno jako Dziecięcia, jak i wówczas, gdy został złożony w grobie. Tak o tym wydarzeniu i jego znaczeniu pisze Newman:

Narodził się w ciemności, w ciemną noc, w jaskini, w której przebywało bydło, w nieprzyjaznym żłóbku [...] Sam nie uległ jednak mrokowi; wszedł do pieczary, po to, by ją opuścić [...] Zamierzał przemienić ziemię i zaczął „w najniższym dole, w miejscu panowania ciemności i w otchłani”. Wszystko miało zostać przez Niego odnowione [...] Położył się więc na wilgotnej ziemi w mroźną noc, a wnet Światło zajaśniało w ciemności ${ }^{11}$.

${ }^{9}$ L. Rosales, Nuevo Retablo de Navidad, „Cuadernos Hispanoamericanos”, t. 29, 1856(84), $\mathrm{nr}$ 2, s. 363.

${ }^{10}$ Por. J.H. Newman, Parochial and Plain Sermons, t. 6, London-New York-Bombay-Calcutta 1907, s. 280.

${ }_{11}$ Tamże, s. 284-285. 
W innym kazaniu The Thought of God, the Stay of the Soul z 1840 roku Newman posługuje się metaforą nocy do podkreślenia nietrwałości dóbr ziemskich, które przemijają wraz z jej upływem i nastaniem dnia. W ten sposób dopełnia on występujący w swoich dziełach obraz świata widzialnego, mającego dwa główne rysy: ulotność i złudność, przy czym ostatnia cecha reprezentowana jest $\mathrm{w}$ jego twórczości przez symbol cienia. We wspomnianym kazaniu zauważa konsekwencję, jaką niesie świadomość zastanego stanu rzeczy: „Nie umieszczamy naszych uczuć w słońcu, księżycu czy gwiazdach, ani w tej bogatej i pięknej ziemi, ponieważ wszystko, co materialne, zanika i przemija jak dzień i noc. Człowiek również, chociaż ma w sobie inteligencję, ale w swoim najlepszym stanie jest całkowicie marnością"12.

\section{3. „Noc” (the night) jako czas ospałości, trwogi i podlegania pokusom}

Metafora nocy wybrzmiewa także w modlitwie poetyckiej autorstwa Lancelota Andrewesa (1555-1626), anglikańskiego biskupa Winchester, pt. Commendation ze zbioru datowanego na rok $1618^{13}$. Newman podjął się tłumaczenia tego dzieła z greki, jako że autor pomimo swoich angielskich korzeni, spisał je w tym języku, uważając za bardziej odpowiedni na potrzeby osobistej modlitwy ${ }^{14}$. W porządku modlitwy porannej obejmującym: litanię, spowiedź oraz powierzenie się opiece Bożej, biskup Andrewes w ostatniej z tych części pisze:

Boże naszych ojców, który cień śmierci przemieniasz w zaranie ${ }^{15}$ i rozświetlasz oblicze ziemi,

12 Tamże, t. 5, London-New York-Bombay-Calcutta 1907, s. 317.

${ }_{13}$ Zob. F.E. Brightman, Introduction, w: The Preces Privatae of Lancelot Andrewes, Bishop of Winchester, London 1903, s. XV. Dzieło zostało wydane całościowo w thumaczeniu angielskim w 1675 roku. Newman najwyraźniej uważał za wartościowe ponowne przetłumaczenie modlitw na bardziej aktualną angielszczyznę, ceniąc biskupa Andrewesa jako zasłużonego teologa i uczonego anglikańskiego, który nadzorował prace redakcyjne i był jednym z tłumaczy tzw. „Biblii w wersji króla Jakuba" (King James Version of Bible). Ponadto biskup Andrewes znany był z dzieła Ninety-six Sermons, a jego pobożność wzbudzała podziw, jako że przeznaczał pięć godzin w ciągu dnia na modlitwę - por. A. Hanson, H.B. Swete, Introduction, w: The Devotions of Bishop Andrewes, t. 1, b.m.w. 1920, b.p., https://www.amazon.com/dp/B002HMCILI/ref=rdr_kindle_text_tmb\#reader_B002HMCILI [dostęp: 26.12.2018].

${ }^{14}$ Biskup Andrewes nie pisał modlitw z intencją ich publikacji, stąd także zrozumiałe jest użycie przez niego greki zamiast języka ojczystego. Mimo to jego manuskrypt ocalał, przekazany na łożu śmierci przyjacielowi, Williamowi Laudowi, późniejszemu arcybiskupowi Canterbury.

${ }^{15}$ Por. „O Boże, Przedwieczny Królu, który oddzielasz dzień od nocy i cień śmierci przemieniasz w poranek" - The Book of Common Prayer, dz. cyt., s. 56, 99. 
który odtrącasz ciemność od oblicza światła, przepędzasz noc i przywracasz dzień, który rozświetlasz moje oczy, abym nie zasnął śmiertelnie ${ }^{16}$ [...]

Daj mi być dzieckiem światła, synem dnia, Jak za dnia kroczyć trzeźwo, święcie i uczciwie ${ }^{17}$.

Modlitwa ta ukazała się w zbiorze modlitw opublikowanym przez Newmana 25 marca 1840 roku w Traktacie 88 (jednym z dziewięćdziesięciu traktatów, niezwykle ważnych dla ruchu oksfordzkiego dążącego do odnowienia anglikanizmu przez publikację w nich myśli ojców Kościoła oraz znaczących teologów anglikańskich). Jak można zauważyć, pod względem treści wyraźnie nawiązuje ona do modlitwy brewiarzowej, a przy uwzględnieniu również struktury (wyznanie winy, Confession of Sin) także do oficjum modlitwy porannej i wieczornej z Book of Common Prayer. Fragment ten ukazuje noc jako czas snu, panowania ciemności i śmierci. Ostatnie zaś stwierdzenie wyrażające pragnienie bycia „synem dnia”, który kroczy pewnie, w świętości i uczciwości, nasuwa na myśl obraz przeciwstawny, tożsamości „syna nocy”, którego cechują ospałość, nieprawość i niepewność. Implicite jest to więc także pora braku zachowania czujności oraz przywiązania do grzechu i zła.

Podobny wydźwięk metafory nocy niesie modlitwa wieczorna z Book of Common Prayer, z której każdy pastor, w tym John Henry Newman i biskup Andrewes, miał obowiązek korzystać. Obaj prosili słowami nawiązującymi do poprzedniego wezwania:

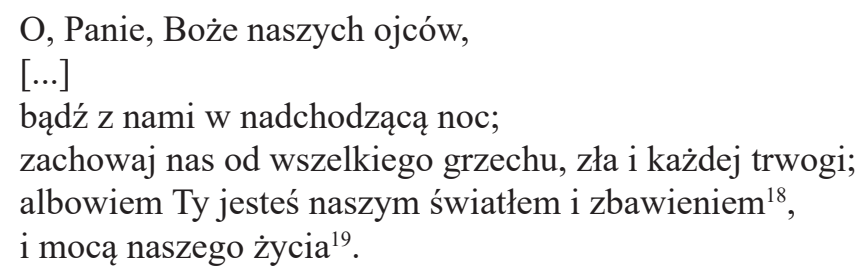

Obie modlitwy, biskupa Andrewesa i z Book of Common Prayer, oprócz rzeczywistości nocy utożsamionej ze stanem świata po grzechu pierworodnym, ukazują również Boga, który w swojej wszechmocy może go odmienić. Pierwsza modlitwa podkreśla Jego udział w przezwyciężeniu śmierci

${ }_{16}$ Por. Ps 13,4 .

${ }_{17}$ Por. 1 Tes 5,5-8; J.H. Newman, Rozmyślania i modlitwy..., dz. cyt., s. 422; tenże, Tracts for the Times, nr 88, b.m.w. 2007, s. 8-9.

${ }^{18}$ Por. Ps $27,1$.

19 The Book of Common Prayer, dz. cyt., s. 113. 
i grzechu, które zdają się wzajemnie łączyć, druga natomiast upatruje mocy Boga w pokonaniu jednakowoż nocnej trwogi. Lęk został tym samym ukazany jako pewien rodzaj zła, który przeszkadza wierzącemu w pełnieniu woli Bożej.

\section{4. „Zaciemnienie przez noc" (to dim ere night) i ,zdezorientowa- nie pośród nocy" (bewildered in night) jako skutek utraty laski uświęcającej}

Inne znaczenie metafory nocy odsłania wiersz św. Grzegorza z Nazjanzu, który John Henry Newman zawarł w autorskim zbiorze poezji z 1834 roku, wespół z najbardziej poruszającymi go utworami ojców Kościoła. Umieścił go także ponownie przy okazji charakterystyki tego kapadockiego ojca w Historical Sketches z 1867 roku:

O, Najświętsza Prawdo! Jakże zgrzeszyłem przeciw Tobie!

W dniu Twojego święta chciałem złożyć przed Tobą przysięgę wierności,

Ale zostałem zaciemniony przez noc.

Teraz pomimo to, wznoszę moją modlitwę i widzę, że nadal jestem zdolny,

Zachować w sobie Twój poranny promień,

Nieskalany i jasny.

Ale stało się, moja stopa potknęła się, a gdy leżałem, przystąpił do mnie on,

Mój ponury wróg i okradł mnie z niebiańskiego płomienia.

Teraz zaś proszę Cię, Panie, wchłoń moją ciemność, dopóki jestem światłem ${ }^{20}$.

Warto zauważyć, że wyznanie św. Grzegorza „moja stopa potknęła się”, świadczy, iż w omawianym utworze pojawia się motyw wędrówki człowieka przez życie, na co wskazuje pora dnia, w której peregrynacja ta się dokonuje, chociaż nie została dokładnie określona. Jeśli jednak przyjąć, że „poranny promień” i „niebiański płomień” są metaforami łaski wiary i świętości otrzymanej podczas chrztu, to Grzegorz z Nazjanzu ukazuje tę drogę jako mającą miejsce w ciągu dnia, w czasie trwania którego zapadająca ciemność jest wynikiem utraty łaski uświęcającej, a więc wewnętrznego światła.

Na taką interpretację mogłyby wskazywać słowa zawarte w Traktacie 76 Newmana z 1840 roku, w którym pojawiają się wszystkie motywy z utworu

20 J.H. Newman, Verses on Various Occasions, London-New York-Bombay 1903, s. 199; tenże, Historical Sketches, t. 2, London-New York-Bombay 1906, s. 87-88. Podobną wymowę ma inna modlitwa św. Grzegorza z Nazjanzu, w której Bóg ukazany jest jako Światło rozpraszające ciemność nocy, tj. grzechu - por. Grzegorz z Nazjanzu, The Evening Hymn, https://iconandlight.wordpress. com/2016/12/27/an-evening-hymn-st-gregory-nazianzen/ [dostęp: 1.01.2019]. 
św. Grzegorza z Nazjanzu: wędrówka, upadek-ciemność i droga. Zawiera on kompilację różnych wypowiedzi teologów anglikańskich na temat chrztu. Interesujący nas fragment zostaje przywołany przez Newmana za Several Discourses Preached at the Temple Church Thomasa Sherlocka (1678-1761), biskupa Londynu: „Przez chrzest bramy niebios stoją przed nami otworem i prowadzi do nich droga wybrukowana, abyśmy mogli wrócić do ojczystego kraju [...] ale jak często on [chrześcijanin - N.L.] potyka się i upada jak inni ludzie, a czasem gubi drogę i błąka się długo, zdezorientowany pośród nocy i ciemności?"21.

Porównując te dwa utwory, św. Grzegorza i biskupa Sherlocka, zauważyć można, że tak jak łaska uświęcająca jest dla tego pierwszego światłem w drodze, tak dla Sherlocka wiąże się w sposób szczególny z sakramentem chrztu; stanowi umocnienie tej drogi i przyczynę usprawiedliwienia. Tymczasem ciemność nocy u obu tych pisarzy, których myśli Newman włączył do swych dzieł, oznacza stan człowieka upadłego, który dając przez grzech przystęp do siebie złemu duchowi, naraża swoje życie na niebezpieczeństwo wiecznego potępienia.

\section{5. „Ciemność nocy” (the darkness of night) objawiająca stan fizycznej bezbronności i niewiedzy co do rzeczy ostatecznych}

Metafora nocy obecna jest u Johna Henry'ego Newmana także w jego kazaniu The Intermediate State, $\mathrm{w}$ trzecim zbiorze Parochial and Plain Sermons z 1836 roku, w którym jako anglikanin dowodził, że stan spoczynku świętych na łonie Abrahama, mający miejsce między śmiercią a sądem ostatecznym, jest słuszną zapłatą za cierpienia doznane w życiu doczesnym ${ }^{22}$. Wśród niebezpieczeństw, na które każdy człowiek narażony jest na ziemi, wymienia „gwałtowność żywiołów” (the fury of the elements) i „ciemność nocy" (the darkness of night) ${ }^{23}$. Ta ostatnia zostaje przedstawiona przez niego w sposób dosłowny i przenośny. Według Newmana istnieje bowiem realne zagrożenie egzystencji ludzkiej ze strony świata przyrody, np. gdy zgodnie $\mathrm{z}$ jego prawami nastaje zmrok, odbierający osobie poczucie bezpieczeństwa i możliwość obrony w przypadku bezdomności ${ }^{24}$. Jednocześnie, odnosząc się do sensu alegorycznego, uważa, że człowiekowi przez całe życie towarzyszy

21 J.H. Newman, The Tracts for the Times, nr 76, b.m.w. 2007, s. 43-44.

22 Jest to interpretacja Newmana Ap 6,11 - por. tenże, Parochial and Plain Sermons, t. 3, London-New York-Bombay-Calcutta 1907, s. 366, 371.

23 Tamże, s. 370.

${ }^{24}$ Por. tamże. 
zaciemnienie świadomości przejawiające się w niewiedzy co do spraw ostatecznych i świata niewidzialnego ${ }^{25}$.

\section{6. „Ciemna noc” (the dark night) odpowiadająca postawie sceptycznej}

Inne znaczenie metafory nocy niesie powieść Newmana pt. Loss and Gain, wydana trzy lata po jego konwersji w odpowiedzi na inne dzieło o tym samym tytule, skierowane przeciw oksfordzkim konwertytom. W wykreowanej przez siebie fikcji literackiej Newman przedstawia prawdziwe pobudki, jakie towarzyszą takim osobom, ujawniając jednocześnie osobiste motywy konwersji. Powieść ta od 1848 roku doczekała się kilku wydań, w tym ostatniego za życia Newmana w 1874, w którym zawarł dedykację adresowaną do Charles'a W. Russella (1812-1880), katolickiego duchownego, wykładowcy historii Kościoła w irlandzkim Maynoonth University i rektora tamtejszego seminarium. Właśnie pisma doktora Russella oraz cechy jego charakteru, takie jak brak skłonności do pouczającego tonu i życzliwość pomimo przynależności do odmiennej konfesji, przyczyniły się do konwersji Newmana ${ }^{26}$. W swojej powieści John Henry opisuje następującą drogę, jaką przebywa konwertyta uznający katolicyzm za prawdziwą religię, a Kościół katolicki za swój dom: „,...] wybierając religię podług własnego kryterium [...] ci, którzy są poza Kościołem, muszą zacząć od osobistego osądu i używają go, by ostatecznie go zastąpić; tak jak człowiek, przebywając na dworze, używa lampy w ciemną noc i odkłada ją, kiedy powróci do domu" ${ }^{27}$.

Mając na uwadze szerszy kontekst myśli Newmana, warto zauważyć, że światło lampy oznacza przyświadczenie realne (real assent), które charakteryzuje się pewnością; oba bowiem rozświetlają drogę, która dzięki nim zdaje się być bezpieczna. Ciemna noc natomiast musi określać stan przeciwny, w którym nie jest się zdolnym uznać jakiejś prawdy za pewną i oprzeć na niej swojego życia, jak ma to miejsce w przypadku sceptycyzmu.

\section{7. „Ciemna noc” (the dark night) jako nadzwyczajny czas objawienia się Boga}

John Henry Newman odwołuje się do metafory nocy także w kontekście ciszy i spokoju, jakie ona $\mathrm{z}$ sobą niesie. To w takich okolicznościach

\footnotetext{
25 Por. tamże, s. 371.

26 Por. tenże, Apologia pro vita sua, tłum. S. Gąsiorowski, Warszawa 2009, s. 296-297.

27 Tenże, Loss and Gain. The Story of the Convert, London-New York-Bombay 1906, s. 203.
} 
najwyraźniej można usłyszeć głos Boga i Jego świętych wysłanników, dlatego Newman w przeciwieństwie do Księgi Samuela (1 Sm 3,1-10) podkreśla porę doby, w jakiej miało miejsce wezwanie Samuela, podczas gdy biblijny przekaz wspomina jedynie o czasie snu chłopca. W kazaniu Moses the Type of Christ z 1842 roku zawiera następujący opis tej sceny: „Samuel został zawołany po imieniu, ale nie wiedział, kto go wezwał w ciemną noc, dopóki Eli mu nie powiedział" 28 .

Ponownie metafora nocy zostaje użyta przez Newmana w tym samym kontekście w kazaniu Religious Joy z 1843 roku. Opisuje w nim scenę zwiastowania pasterzom Dobrej Nowiny o narodzinach Bożego Dziecięcia. Jego zdaniem, ci ubodzy mężowie musieli być prawdziwymi przyjaciółmi Boga, skoro pragnął zaprosić ich na tak rodzinne wydarzenie. Kiedy Chrystus został powity w żłobie: ,[...] ubodzy mężowie, zaangażowani w życie pełne trudów, narażeni na mróz i ciemność nocy, obserwowali swoje stada, aby odstraszyć drapieżne zwierzęta i rabusiów [...] tej łaskawej nocy, błogosławione duchy, które służą Chrystusowi i Jego świętym, przemówiły do nich, aby wyrwać ich z prozy codziennego trudu ku wielkiej radości”29.

\section{8. Świtanie ,po ciemnej nocy" (after the dark night) jako obraz wkro- czenia świata $w$ czasy ostateczne ${ }^{30}$}

John Henry Newman, omawiając tytuł maryjny „Gwiazdo zaranna” (Stella matutina $)^{31}$, argumentuje, że kiedy gwiazda ta jest widoczna na granicy nocy i dnia, oznacza, że blisko jest już wschód słońca. Podobnie jest z Maryją, która po wniebowzięciu króluje w Niebie niczym jasna gwiazda, a jej obecność zawsze zwiastuje nadejście Syna ${ }^{32}$. Wraz z tym wydarzeniem świat wkroczył w nowy etap zbawienia - czasy ostateczne - odpowiadające przenośnym ostatnim trzem godzinom nocy przed świtaniem, w których gwiazda ta jest widoczna.

Jednocześnie Newman musiał być świadomy faktu, że ,gwiazda poranna" to jedynie nazwa zwyczajowa planety Wenus, co ma znaczenie s. 122.

${ }^{28}$ Tenże, Parochial and Plain Sermons, t. 7, London-New York-Bombay-Calcutta 1908,

${ }^{29}$ Tamże, t. 8, London-New York-Bombay-Calcutta 1908, s. 247, 250.

${ }^{30}$ Tytuł omawianego w tej części rozważania Newmana to Mary is the „Stella Matutina", the Morning Star - after the Dark Night, but always Heralding the Sun - tenże, Rozmyślania i modlitwy..., dz. cyt., s. 228; tenże, Meditations and Devotions, s. 75.

${ }^{31}$ Zob. tenże, Rozmyślania i modlitwy..., dz. cyt., s. 228-229; tenże, Discourses to Mixed Congregations, dz. cyt., s. 92.

${ }_{32}$ Por. tenże, Rozmyślania i modlitwy..., dz. cyt., s. 229. 
z dogmatycznego punktu widzenia. Porównanie Maryi do planety świecącej światłem odbitym jest bardziej adekwatne z racji jej przywilejów, tj. niepokalanego poczęcia oraz wniebowzięcia, które otrzymała ze względu na Syna, „Słońce sprawiedliwości” (the Sun of Justice) ${ }^{33}$. Przekonanie to zostało wyrażone w pośmiertnie wydanych Rozmyślaniach $i$ modlitwach: ,[...] jest szczególną cechą Maryi, że jest ona Gwiazdą zaranną, zapowiadającą słońce. Nie jaśnieje dla samej siebie, ani z samej siebie, ale jest odbiciem jej i naszego Odkupiciela, i Jego, a nie siebie wysławia. Kiedy ona ukazuje się w ciemności, wiemy, że On jest blisko" ${ }^{34}$.

Obraz ten Newman uzupełnia o kolejne porównania, które czyni w wykładzie Sainliness the Standard of the Christian Principle z 1849, przeznaczonym dla członków oratoriów św. Filipa Neri. Inne ciało niebieskie dobrze widoczne w nocy, Księżyc, sprawiające większe wrażenie od pozostałych, a także świecące światłem odbitym, porównuje z Kościołem. Twierdzi: „spokojny, pogodny Księżyc w nocy [...] wyobraża Jego Kościół"35. Tymczasem „gwiazdy [są - N.L.] niczym dobrzy i święci mężowie, podróżujący w samotnej pielgrzymce do wiecznego odpoczynku!"36.

Światło Księżyca, tak jak i gwiazd, jest nieocenionym wsparciem dla podróżujących w nocy. Newman opisywał w ten sposób sytuację osób ochrzczonych, które będąc w Kościele, mogą wzorować się na świętych, również żyjących na ziemi, ponieważ przez swoją postawę już uczestniczą w chwale nieba i jaśnieją jako przykład dla swych braci. Inne jawi się natomiast położenie ludzi pozbawionych prawdziwej religii objawionej: kroczą oni jak gdyby po omacku przy zachmurzonym niebie, bez żadnego pewnego źródła światła.

W innym wykładzie pt. The Glories of Mary for the Sake of Her Son z 1849 roku na progu ogłoszenia dogmatu o Niepokalanym Poczęciu Maryi, Newman upraszał jej przewodnictwa w drodze do nieba. Nawiązuje w nim do metafory nocy jako całego życia człowieka i dnia jako spotkania z Chrystusem po śmierci: „Droga Matko, mów do nas o Odwiecznym [...] jak gwiazda poranna, która jest twoim symbolem, jasna i harmonijna, oddychająca czystością, opowiadająca o niebie i wprowadzająca pokój. O, zwiastunko dnia! $\mathrm{O}$, nadziejo pielgrzyma! Prowadź nas wciąż, jak prowadziłaś w ciemną noc, przez ponure pustkowie, poprowadź nas do naszego Pana Jezusa, przywiedź nas do domu"37.

\footnotetext{
${ }^{33}$ Tenże, Discourses to Mixed Congregations, dz. cyt., s. 92; por. Mdr 5,7; Ml 3,20.

${ }^{34}$ Tenże, Rozmyślania i modlitwy..., dz. cyt., s. 229.

${ }^{35}$ Tenże, Discourses to Mixed Congregations, dz. cyt., s. 92.

36 Tamże.

37 Tamże, s. 358-359.
} 


\section{Zakończenie}

Metafora ciemnej nocy u Johna Henry'ego Newmana zawarta jest zarówno w jego dziełach z okresu anglikańskiego: Parochial and Plain Sermons, Tracts for the Times, Verses on Various Occasions - jak i katolickiego - Discourses to Mixed Congregations, Historical Sketches i Loss and Gain. Jeśli zauważymy jednak, że przywołane w artykule części traktatów zawierają jedynie myśl cytowaną za anglikańskimi teologami, Thomasem Sherlockiem oraz Lancelotem Andrewesem, a zapiski historyczne prezentują treść poematu św. Grzegorza z Nazjanzu, okaże się, że rozumienie tej metafory przez Newmana można oprzeć tylko na nielicznych przykładach. Zaledwie na kilku jego kazaniach, poezji (ograniczonej do dwóch utworów Prowadź mnie, Światto, Sen Geroncjusza), dwóch wykładach adresowanych do członków oratoriów oraz fragmentach rozważania i powieści.

W kontekście tych zapisków ciemna noc w Newmanowskim ujęciu zawiera w sobie rys głęboko egzystencjalny, który ukazuje życie ludzkie jako drogę mającą swój kres w śmierci. Nie jest to jednak czas tułaczki przepełnionej tragizmem, jak widzieli ją inni egzystencjaliści. Człowiek wprawdzie przemija równolegle do nocy, której doświadcza, ale jest on zdolny wzbudzić W sobie światło wiary. To dzięki temu światłu może oprzeć się na Bogu jako ostoi istnienia i prawdzie. Źródłem światła (Słońcem Sprawiedliwości) jest jedynie Ten, który sam nie podlega czasowi i śmierci. W akcie wiary doświadcza się nadprzyrodzonych promieni na kolejnych etapach życia, które są jakby uchylaniem się zasłony dzielącej dwa światy, dlatego wierzący dostrzega znaki istnienia doskonalszej rzeczywistości jako miejsca swojego przeznaczenia i znajduje siły, by przetrwać tę wyjątkową noc. Dodatkowymi światłami pośród nocy życia są mu Kościół (Księżyc) i jego święci (gwiazdy), a w szczególności Maryja, ukazujący jak przyjmować Boże światło i promieniować nim na innych. W szerszej perspektywie Maryja jest także znakiem końca czasów, bo po wniebowzięciu jaśnieje jako Jutrzenka zapowiadająca paruzję.

Ciemność nocy u Newmana połączona również z chłodem, jaki niesie, podkreśla ponadto stan świata po grzechu pierworodnym, który został naznaczony śmiercią, przemijaniem i wrogością wobec człowieka. Pora ta wynika $\mathrm{z}$ odwrócenia się naturalnego porządku rzeczy na skutek tej skazy, w którym to dzień jest czasem aktywności ludzkiej. Noc obrazuje także kondycję człowieka, który doznaje braków na wielu poziomach: fizycznym w postaci bólu i słabości, psychicznym w formie niewiedzy i ograniczeń umysłowych oraz duchowym, kiedy w wyniku grzechu traci on właściwe rozeznanie w świecie wartości. Niesie ona jednak także sens pozytywny, jej cisza i surowość są okolicznościami, które Zbawiciel wykorzystał dla objawienia swojej chwały zarówno podczas wcielenia, jak i zmartwychwstania. 
THE METAPHOR OF DARK NIGHT IN JOHN HENRY NEWMAN'S WORKS

\section{Summary}

The metaphor of dark night has been deeply rooted by John Henry Newman in the Bible, as evidenced in his sermons. In addition, it results from the inspiration of works of the Fathers of the Church, including St. Gregory of Nazianzus, whose poetry he valued, as well as it was taken over from Anglican theologians, Lancelot Andrewes, Bishop Winchester and Thomas Sherlock, Bishop of London. Apparently, this metaphor resounded in The Pillar of the Cloud, and other works confirm the interpretation that the dark night depicts whole life of man as a pilgrim. Faith helps him to lean on God who leads him home. Certain similarities with this metaphor also occur in the poetry of Luis Rosales, a 20th-century Spanish poet. The dark night is also the season that fell after original sin, making the world unfriendly to man; henceforth he is subject to ignorance, sin and death. However, a believer can see some positive signs that night, which indicate the truth that the world is moving to the end of its path.

Keywords: John Henry Newman; dark night; metaphor; homo viator; „Lead; kindy Light"; world; sin; eschatology; Morning Star (Stella Matutina)

Słowa kluczowe: John Henry Newman; „ciemna noc”; metafora; homo viator; „Prowadź; łaskawe Światło"; świat; grzech; eschatologia; Gwiazda Zaranna

\section{BIBLIOGRAFIA}

Brightman F.E., Introduction, w: The Preces Privatae of Lancelot Andrewes, Bishop of Winchester, London 1903, s. 13-58.

Grzegorz z Nazjanzu, The Evening Hymn, https://iconandlight.wordpress.com/2016/12/27/an-evening-hymn-st-grego-ry-nazianzen/ [dostęp: 1.01.2019].

Hanson A., Swete H.B., Introduction, w: The Devotions of Bishop Andrewes, t. 1, b.m.w. 1920, https://www.amazon.com/dp/B002HMCILI/ref=rdr_kindle_text_tmb\#reader_B002 HMCILI [dostęp: 26.12.2018].

Newman J.H., Apologia pro vita sua, tłum. S. Gąsiorowski, Warszawa 2009.

Newman J.H., Discourses to Mixed Congregations, London-New York-Bombay 1906.

Newman J.H., Historical Sketches, t. 2, London-New York-Bombay 1906.

Newman J.H., Loss and Gain. The Story of the Convert, London-New York-Bombay 1906.

Newman J.H., Meditations and Devotions, London-New York-Bombay-Calcutta 1907.

Newman J.H., Parochial and Plain Sermons, t. 3, London-New York-Bombay-Calcutta 1907.

Newman J.H., Parochial and Plain Sermons, t. 4, London-New York-Bombay-Calcutta 1909.

Newman J.H., Parochial and Plain Sermons, t. 5, London-New York-Bombay-Calcutta 1907.

Newman J.H., Parochial and Plain Sermons, t. 6, London-New York-Bombay-Calcutta 1907.

Newman J.H., Parochial and Plain Sermons, t. 7, London-New York-Bombay-Calcutta 1908.

Newman J.H., Parochial and Plain Sermons, t. 8, London-New York-Bombay-Calcutta 1908.

Newman J.H., Rozmyślania i modlitwy. Poezje, thum. Z. Kubiak, Warszawa 1995. 
Newman J.H., Sen Geroncjusza, w: Rozmyślania i modlitwy. Poezje, tłum. Z. Kubiak, Warszawa 1995, s. 509-546.

Newman J.H., The Dream of Gerontius, w: Verses on Various Occasions, London-New York-Bombay 1903 , s. 323-370.

Newman J.H., The Tracts for the Times, n. 76, The National Institute for Newman Studies, b.m.w. 2007.

Newman J.H., Tracts for the Times, n. 88, The National Institute for Newman Studies, b.m.w. 2007.

Newman J.H., Verses on Various Occasions, London-New York-Bombay 1903.

Pismo Święte Starego i Nowego Testamentu. Biblia Tysiaclecia, Poznań $2003^{4}$.

Rosales L., Nuevo Retablo de Navidad, „Cuadernos Hispanoamericanos”, t. 29, 1856 (84), n. 2, s. 361-365.

The Book of Common Prayer, https://www.bcponline.org/ [dostęp: 29.12.2018].

The noche iremos. Kanony z Taize, http://cantusmundi.blog spot.com/2013/01/de-noche-taize. html [dostęp: 28.12.2018].

Natasza Lisowska - doktorantka w Zakładzie Filozofii Chrześcijańskiej na Wydziale Teologicznym UAM. Interesuje się myślą Johna Henry’ego Newmana, synejdezjologią oraz problematyką konwersji na katolicyzm. 